\title{
The effects of trace elements, cations, and environmental conditions on protocatechuate 3,4-dioxygenase activity
}

\author{
Andréa Scaramal da Silva ${ }^{1}$, Rodrigo Josemar Seminoti Jacques ${ }^{2}$, Robson Andreazza ${ }^{1,3 *}$, Fátima Menezes Bento ${ }^{4}$, Flávio \\ Anastácio de Oliveira Camargo ${ }^{1}$
}

\author{
IUFRGS/FA - Depto. de Solos - Lab. de Microbiologia do \\ Solo - Av. Bento Gonçalves, 7712 - 91540-000 - Porto \\ Alegre, RS - Brasil. \\ 2UFSM - Depto. de Solos, Av. Roraima, 1000 - 97105-900 \\ - Santa Maria, RS -Brasil. \\ ${ }^{3}$ UFPel/Centro de Engenharias, Av. Almirante Barroso, 1734 \\ - 96010-280 - Pelotas, RS - Brasil. \\ ${ }^{4}$ UFRGS/Instituto de Biociências - Depto. de Microbiologia, \\ R. Sarmento Leite, 500, Centro - 90050-170 - Porto \\ Alegre, RS - Brasil. \\ *Corresponding author <robsonandreazza@yahoo.com.br>
}

Edited by: Jussara Borges Regitano

Received October 13, 2011

Accepted January 28, 2013

\begin{abstract}
Phenanthracene is a highly toxic organic compound capable of contaminating water and soils, and biodegradation is an important tool for remediating polluted environments. This study aimed to evaluate the effects of trace elements, cations, and environmental conditions on the activity of the protocatechol 3,4-dioxygenase $(\mathrm{P} 3,40)$ enzyme produced by the isolate Leifsonia sp. in cell-free and immobilized extracts. The isolate was grown in Luria Bertani broth medium (LB) amended with $250 \mathrm{mg} \mathrm{L}^{-1}$ of phenanthrene. Various levels of $\mathrm{pH}$ (4.0-9.0), temperature $\left(5-80{ }^{\circ} \mathrm{C}\right)$, time $(0-90 \mathrm{~min})$, trace elements $\left(\mathrm{Cu}^{2+}, \mathrm{Hg}^{2+}\right.$ and $\left.\mathrm{Fe}^{3+}\right)$, and cations $\left(\mathrm{Mg}^{2+}, \mathrm{Mn}^{2+}, \mathrm{K}^{+}\right.$ and $\mathrm{NH}_{4}{ }^{+}$) were tested to determine which conditions optimized enzyme activity. In general, the immobilized extract exhibited higher enzyme activity than the cell-free extract in the presence of trace elements and cations. Adding iron yielded the highest relative activity for both cell-free and immobilized extracts, with values of 16 and $99 \%$, respectively. Copper also increased enzyme activity for both cell-free and immobilized extracts, with values of 8 and $44 \%$, respectively. Enzyme activity in the phosphate buffer was high across a wide range of $\mathrm{pH}$, reaching $80 \%$ in the $\mathrm{pH}$ range between 6.5 and 8.0. The optimum temperatures for enzyme activity differed for cell-free and immobilized extracts, with maximum enzyme activity observed at $35^{\circ} \mathrm{C}$ for the cellfree extract and at $55^{\circ} \mathrm{C}$ for the immobilized extract. The cell-free extract of the P3,40 enzyme exhibited high activity only during the first 3 min of incubation, when it showed $50 \%$ relative activity, and dropped to $0 \%$ after 60 min of incubation. By contrast, activity in the immobilized extract was maintained during 90 min of incubation. This isolate has important characteristics for phenanthrene biodegradation, producing high quantities of the P3,40 enzyme that forms part of the most important pathway for PAH biodegradation.

Keywords: enzyme activity, enzyme immobilization, biodegradation, waste treatment
\end{abstract}

\section{Introduction}

Polycyclic aromatic hydrocarbons (PAH) are highly toxic compounds that pose risks to humans and animals. Factors such as trace elements and environmental conditions interfere with microorganisms' metabolisms for $\mathrm{PAH}$ biodegradation. Studies on biodegradation have revealed its significant promise for reducing pollution and cleaning up polluted sites (Tao et al., 2007; Chang et al., 2011; Janbandhu and Fulekar, 2011). Bioremediation of PAH-contaminated areas using biodegradation techniques may be an efficient alternative for removing these contaminants from the environment.

Enzymes used for degradation can be divided into two groups: peripheral and fission enzymes. Peripheral enzymes are responsible for recognizing and converting the PAHs in degradable molecules, and fission enzymes pass these molecules through the common pathways for energy generation and carbon routing in the microbial cells (Mishra et al., 2001). The enzyme protocatechol 3,4dioxygenase $(\mathrm{P} 3,4 \mathrm{O})$ (EC 1.13.11.3) cleaves the aromatic ring to form the intermediary compound protocatechol. The extradiol enzymes open the aromatic ring adjacent to the hydrocarboxilic carbons. However, the meta pathway that originates the 2-hydroximuconic semialdehyde will be transformed in pyruvate and acetaldehyde. In this pathway, catechol 2,3-dioxygenase belongs to the class of enzymes that cleave the aromatic ring to form the core intermediary catechol, and protocatechol 4,5dioxygenase to the class that cleave the aromatic ring to form the compound protocatechol (Caldwell, 2000). However, enzyme activity and its applicability for biodegradation require more study.

Protocatechol 3,4-dioxygenase belongs to the class of enzymes that cleave the intradiol group. It contains the Fe (III) as a prosthetic group and many subunits $\alpha$ and $\beta$ form different quaternary structures $(\alpha \beta)_{n}$, where $n$ is a number varying between 3 and 12 (Harayama et al., 1992). Some microorganisms can produce $\mathrm{P} 3,4 \mathrm{O}$ for the biodegradation of organic compounds, including Acinetobacter lwoffii (Kahng et al., 2002), Acinetobacter calcoaceticus (Zaborsky and Schwartz, 1974), and Pseudomonas aeruginosa (Ohlendorf et al., 1987). However, more studies are needed to understand the behavior this enzyme with other isolates and under other conditions.

The use of enzymes can be an efficient alternative for remediation of environments contaminated with PAHs. Enzymes can be used to treat contaminated environments in different ways. Furthermore, enzymes have many advantages over conventional treatments such as chemical complexation (Durán and Esposito, 2000). Enzyme immobilization promotes beneficial effects for cat- 
alytic efficiency as well as for kinetics and stability properties (Degaldillo and Rodriguez-Nogales, 2005). It also offers some advantages for bioremediation (FernandezLafuente et al., 2000). However, trace elements, cation ions, and environmental conditions can interfere with the activity of the P3,4O enzyme. The aim of this study was to evaluate the effect of trace elements, cations, and environment conditions on cell-free and immobilized P3,40 enzyme activity.

\section{Materials and Methods}

Microorganism, media, and growth conditions - An aromatic hydrocarbon degrading microbial consortium was obtained from the enrichment culture of a petrochemical landfarm (Jacques et al., 2007). From this consortium, the $16 \mathrm{~S}$ rRNA region of Isolate 6 was sequenced. The sequence obtained was compared with the most similar sequences retrieved from GenBank and the results did not show an exact classification for this bacterium (Jacques et al., 2007; 2009). Thus, Isolate 6 was characterized as a member of the genus Leifsonia with 98 $\%$ similarity (Figure 1).

The Leifsonia sp. was inoculated in Erlenmeyer flasks with Luria Bertani broth (LB) amended with $250 \mathrm{mg} \mathrm{L}^{-1}$ of phenanthrene as fine crystals (MerckTM, Darmstadt, Germany). The LB broth medium was composed of $5.0 \mathrm{~g} \mathrm{~L}^{-1}$ of meat extract; $10.0 \mathrm{~g} \mathrm{~L}^{-1}$ of tryptone; and $10.0 \mathrm{~g} \mathrm{~L}^{-1}$ of $\mathrm{NaCl}$. All solutions were diluted in deionized water. The $\mathrm{pH}$ was adjusted to 7.0 by adding aliquots of either $\mathrm{HCl}$ or $\mathrm{NaOH}$. The media were sterilized by autoclaving at $121^{\circ} \mathrm{C}$ for 20 min. Flasks were incubated at $30{ }^{\circ} \mathrm{C}$ with orbital shaking $(150 \mathrm{rpm})$ with three replicates. After growth, cells were harvested by centrifuging $(10,000 \mathrm{rpm})$ for 15 $\min$ at $4{ }^{\circ} \mathrm{C}$.

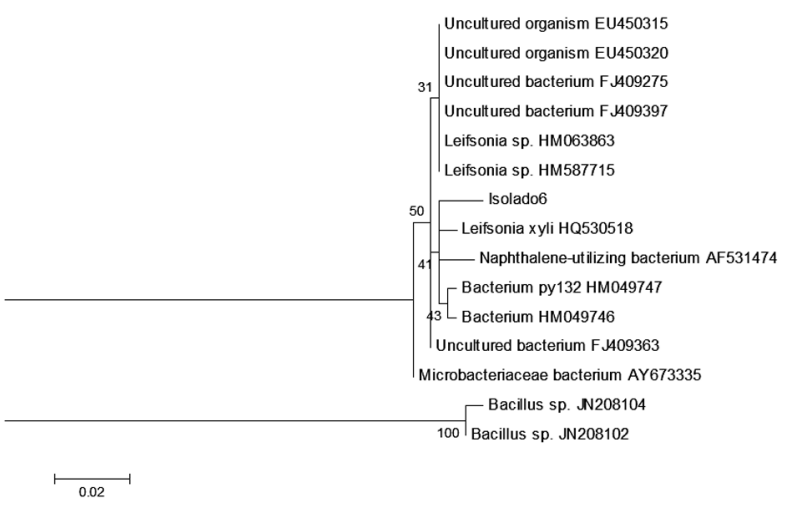

Figure 1 - Phylogenetic tree showing the affiliations of the isolate obtained in this study and isolates retrieved from GenBank. The numbers at branch points indicate bootstrap values based on 1000 replicates. Molecular phylogenetic analysis was carried out with the Maximum Likelihood method. The evolutionary history was inferred by using the Maximum Likelihood method based on the Tamura-Nei model.
Enzyme immobilization - The enzyme was immobilized using the sodium alginate matrix technique /Giedraityte and Kalediene, 2009). One milliliter of crude extract (9000 U) was suspended in $9 \mathrm{~mL}$ of $2 \%(\mathrm{w} / \mathrm{v})$ sodium alginate prepared in $50 \mathrm{mM}$ Tris- $\mathrm{HCl}$ buffer solution ( $\mathrm{pH}$ 8.0). After homogenization of the mixture, the enzyme was added with a dropper to $100 \mathrm{~mL}$ of solution of $0.2 \mathrm{M} \mathrm{CaCl}_{2}$. Upon contact with the solution, the drops gelled to form regularly-sized spheres (3 $\mathrm{mm}$ diameter), and these remained in the solution under gentle agitation to complete gel formation. After $1 \mathrm{~h}$ incubation, the beads were removed, washed twice with sterile distilled water and stored at $4{ }^{\circ} \mathrm{C}$.

Enzyme activity - The enzyme activity of the both cell-free and immobilized P3,40 enzyme was assayed spectrophotometrically (absorbance at $\lambda=290 \mathrm{~nm}$ ), corresponding to the formation of cis-muconic acid. The reaction mixtures contained $1 \mathrm{~mL}$ of soluble or immobilized enzyme preparations; $1 \mathrm{~mL}$ of $0.12 \mathrm{mM}$ protocatechol acid; and $1.0 \mathrm{~mL}$ of the $50 \mathrm{mM}$ Tris- $\mathrm{HCl}$ buffer solution ( $\mathrm{pH} 7.5$ ), as described by Fujisawa and Hayaishi (1968). All determinations were made in duplicate for each sample. After the addition of the enzymes to the cell-free and immobilized extracts, mixtures were incubated in water baths at 35 and $55{ }^{\circ} \mathrm{C}$, respectively. At regular time intervals thereafter, aliquots were used to monitor the reaction progress in the spectrophotometer.

Effects of trace elements and cations - The trace elements tested were $\mathrm{Cu}^{2+}, \mathrm{Hg}^{2+}$, and $\mathrm{Fe}^{2+}$. The cations tested were $\mathrm{NH}_{4}{ }^{+}, \mathrm{Mg}^{2+}, \mathrm{Mn}^{2+}$, and $\mathrm{K}^{+}$. All trace elements and cations were tested at concentrations of $1.0 \mathrm{mM}$, with the exception of $\mathrm{NH}_{4}{ }^{+}$, which was tested at $10 \mathrm{mM}$. Each cation and metal was dissolved in $50 \mathrm{mM}$ Tris- $\mathrm{HCl}$ buffer solution $(\mathrm{pH} 8.0)$ at $25^{\circ} \mathrm{C}$ in the cell-free extract. The chemicals used were copper sulfate, mercury chloride, iron chloride, magnesium chloride, manganese chloride, potassium acetate, and ammonium sulfate.

Effects of $\mathbf{p H}$, temperature, and time - Optimum $\mathrm{pH}$ was determined by measuring activity at $30^{\circ} \mathrm{C}$ over the $\mathrm{pH}$ range of 4.0 to 9.0 , using the following buffers: 50 $\mathrm{mM}$ acetate ( $\mathrm{pH} 4.0,4.5,5.0$, and 5.5), $50 \mathrm{mM}$ phosphate $(\mathrm{pH} 6.0,6.5,7.0,7.5$, and 8.0), and $50 \mathrm{mM}$ Tris- $\mathrm{HCl}$ (pH 7.0, 7.5, 8.0, 8.5, and 9.0). Optimum temperature was determined by assaying enzyme activity at various temperatures (from 5 to $50{ }^{\circ} \mathrm{C}$ ). Temporal variation in enzyme activity was determined by measuring enzyme activity during $90 \mathrm{~min}$, at 10 -min intervals. In the temperature and temporal tests Tris- $\mathrm{HCl}$ buffer $(50 \mathrm{mM}, \mathrm{pH}$ 8.0) was used because both cell-free extract and immobilized enzyme had the highest activity at the alkaline medium in these soils.

Effects of trace elements and cations - Different trace elements and cations exhibited different effects on the enzyme activity of the $\mathrm{P} 3,4 \mathrm{O}$ (Figure 2). In general, the 
immobilized extract exhibited higher activity than the cell-free extract with the presence of the trace elements and cations, except in the case of $\mathrm{Mn}^{2+}$. Enzyme activity of the $\mathrm{P} 3,4 \mathrm{O}$ in the cell-free extract was highly inhibited in the presence of $\mathrm{K}^{+}, \mathrm{NH}^{4+}$, and $\mathrm{Mg}^{2+}$, with relative activity declining by 83, 69 and $66 \%$, respectively. The inhibition of the immobilized extract was low for $\mathrm{K}^{+}$and $\mathrm{Mg}^{2+}$, with relative activity values of 14 and $36 \%$, respectively. The presence of ammonium with the P3,4O exhibited the same level of inhibition for both cell-free and immobilized extract of the enzyme activity.

Among the trace elements, iron showed the highest relative activity for both cell-free and immobilized extract with values of 16 and $99 \%$, respectively (Figure 2). Copper also increased enzyme activity for both cellfree and immobilized extract with values of 8 and $44 \%$, respectively. Although $\mathrm{Hg}$ inhibited enzyme activity of the cell-free extract, it greatly increased activity of the immobilized extract, by $40 \%$. Immobilization protected the enzyme from the deleterious effects of $\mathrm{K}^{+}$and $\mathrm{Hg}^{+2}$ and also increased enzyme activity in the presence of $\mathrm{Fe}^{+3}$ and $\mathrm{Cu}^{+2}$.

Effects of pH - Activity of the P3,40 enzyme produced by the isolate Leifsonia sp. peaked at pH 8.0 in the Tris$\mathrm{HCl}$ buffer with almost $100 \%$ of relative activity (Figure 3). The phosphate buffer exhibited high enzyme activity, reaching $80 \%$ in the $\mathrm{pH}$ range between 6.5 and 8.0. The activity of the $\mathrm{P} 3,4 \mathrm{O}$ in acetate buffer was up to $40 \%$ in the $\mathrm{pH}$ range between 4.0 and 5.5, showing that this enzyme is very active over a wide range of $\mathrm{pH}$ values.

Enzyme activity of the $\mathrm{P} 3,4 \mathrm{O}$ was high at $\mathrm{pH} 7.5$ in the phosphate buffer for both cell-free and immobilized extract (Figure 3). In general, immobilization of the P3,4O enzyme with sodium alginate yielded an increase in stability, increasing the $\mathrm{pH}$ range with high enzyme

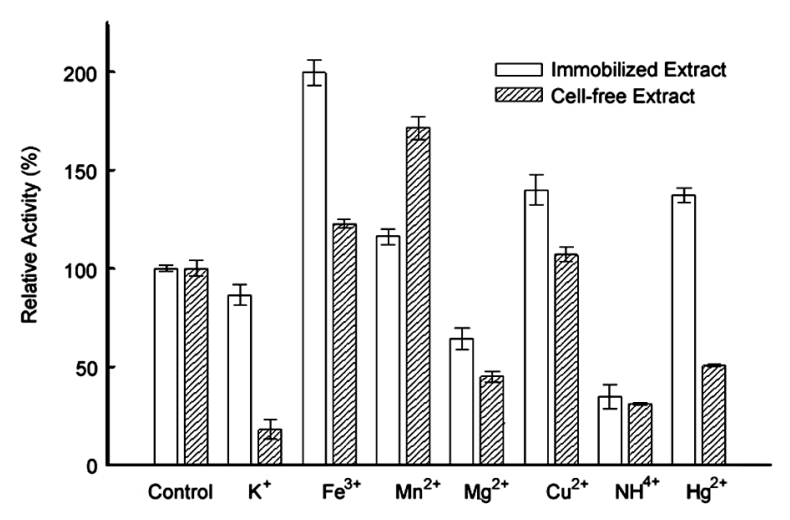

Figure 2 - Effects of trace elements and cations on the relative enzymatic activity of the protocatechol 3,4-dioxygenase (P3,40) produced by Leifsonia sp. in the cell-free and immobilized extracts. Error bars represent standard errors. The control treatment was enzyme activity in the absence of the ions. activity. The immobilized extract showed high enzyme activities in the $\mathrm{pH}$ range between 4.0 and 6.5 (between 40 and $75 \%$ of relative activity), and in the $\mathrm{pH}$ range between 8.0 and 9.0 (relative activity above $80 \%$ ). The immobilization of the $\mathrm{P} 3,4 \mathrm{O}$ enzyme exhibited the best results of enzyme activity in the different $\mathrm{pH}$ ranges.

Effects of temperature - The cell-free and immobilized extracts of $\mathrm{P} 3,4 \mathrm{O}$ enzyme exhibited different behaviors (Figure 4). Enzyme activity of the P3,4O for the cell-free extract was high until $40{ }^{\circ} \mathrm{C}$ and decreased substantially above that temperature. By contrast, enzyme activity of the immobilized extract was high only for tempera-

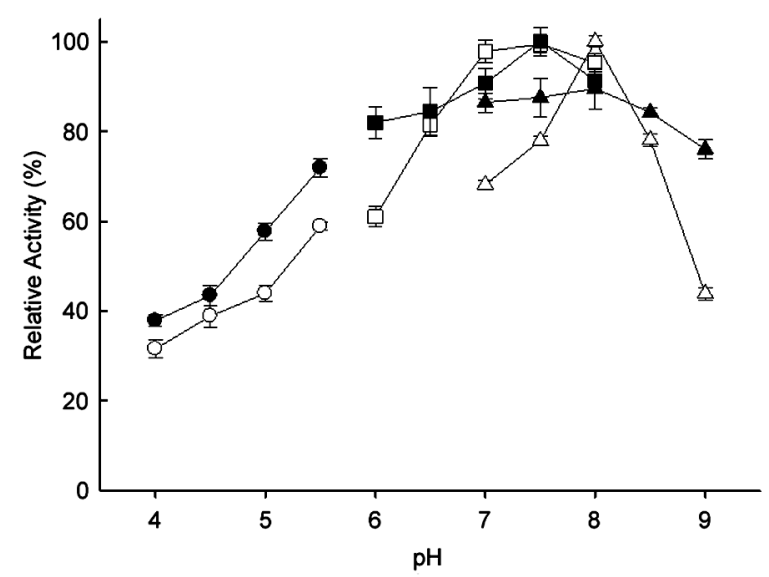

Figure 3 - Effects of variation in pH on protocatechol 3,4-dioxigenase activity in the cell-free extract (white symbols) and the immobilized extract (black symbols) of a Leifsonia sp. Buffers: acetate (from $\mathrm{pH} 4.0$ to 5.5 - circle symbols), phosphate (from pH 6.0 to 8.0 - square symbols), and tris- $\mathrm{HCl}$ (from $\mathrm{pH} 7.0$ to 9.0 - triangle symbols). Error bars are standard errors of the means.

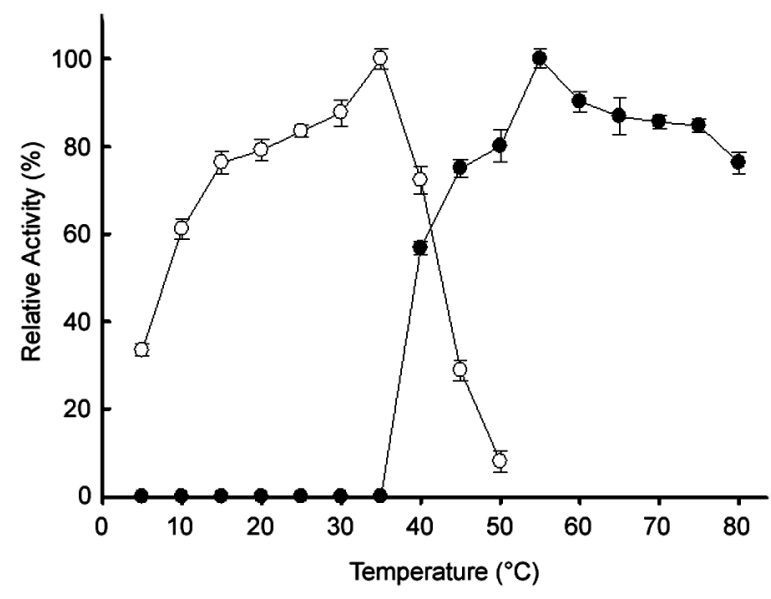

Figure 4 - Effects of different temperatures of the cell-free (white symbols) and immobilized (black symbols) extracts on the relative activity of the protocatechol 3,4-dioxygenase produced by Leifsonia sp., after 30 min of incubation. Error bars are the standard errors of the means. 
tures greater than $40^{\circ} \mathrm{C}$. The optimum temperature of the enzyme activity was different for the cell-free and immobilized extracts, with maximum enzyme activities observed at $35{ }^{\circ} \mathrm{C}$ and $55^{\circ} \mathrm{C}$, respectively. In summary, the cell-free extract exhibited high enzyme activity (up to $60 \%$ ) in the temperature range between 10 and 40 ${ }^{\circ} \mathrm{C}$, while immobilization of the enzyme increased the optimum $\mathrm{pH}$ range with high enzyme activity in the temperature range between 45 and $80{ }^{\circ} \mathrm{C}$, with activity values around $80 \%$ of relative activity.

Effects of time - Temporal variation of P3,40 enzyme activity for both cell-free and immobilized extracts showed the same pattern, decreasing over time (Figure 5). A relative activity of $100 \%$ was only achieved at the starting time. The cell-free extract of the P3,40 enzyme exhibited high activity only for the first $30 \mathrm{~min}$ of incubation, during which it showed $50 \%$ of relative activity, and achieved values close to $0 \%$ activity after $50 \mathrm{~min}$ of incubation. The immobilized enzyme maintained a relative activity of more than $50 \%$ for the first $45 \mathrm{~min}$. Furthermore, immobilization of the $\mathrm{P} 3,4 \mathrm{O}$ maintained enzyme activity during the first $90 \mathrm{~min}$ of incubation. For all time periods, enzyme activity of the immobilized extract was higher than that of the cell-free extract (Figure 5), indicating that immobilization could be the best way to use the $\mathrm{P} 3,4 \mathrm{O}$ enzyme.

\section{Discussion}

PAHs are recalcitrant compounds with high toxicity and carcinogenic properties for humans and animals (Costantini et al., 2009). PAH pollution requires efficient treatments for cleaning up the environment and reducing the risks these compounds pose for living

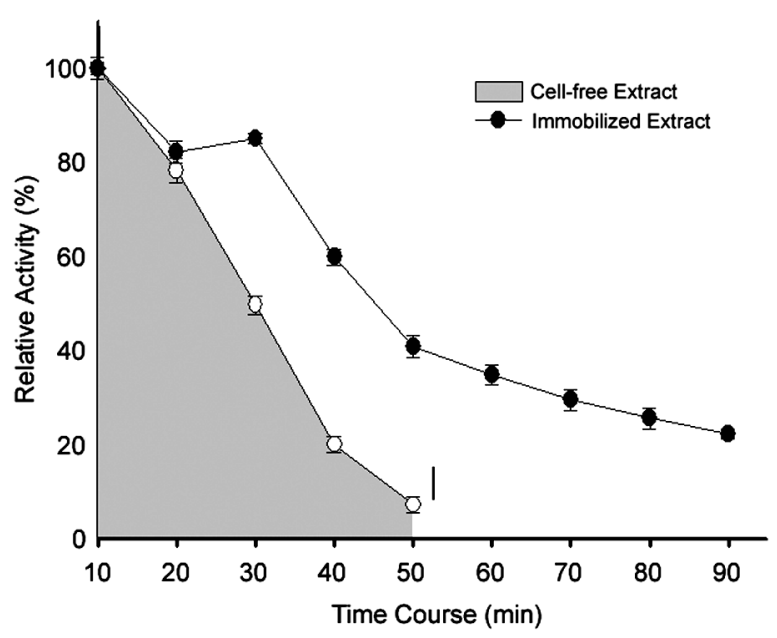

Figure 5 - Variation over time of the relative activity of the protocatechol 3,4-dioxygenase (P3,40) in the cell-free extract and immobilized extract produced by a Leifsonia sp. Error bars are the standard errors of the means. organisms. One such treatment is high-efficiency biodegradation using enzymes produced by microorganisms (Chang et al., 2011; Janbandhu and Fulekar, 2011). The enzyme protocatechol 3,4-dioxygenase (P3,4O) plays an important role in some pathways for biodegrading PAHs, including phenanthrene. However, trace elements, cations, and environmental conditions are important influences on enzyme activity and consequently for biodegradation.

Cations and heavy metals were added to the reaction mixture as sulfate, acetate, and chloride, all inexpensive compounds. These products can thus be easily used in bioreactors, if bioremediation technology is adopted at a large scale by industry. $\mathrm{Fe}^{3+}$ increased P3,4O enzyme activity up to $71 \%$. Iron is an important trace element for many cellular functions, where it is intrinsically linked with the metabolism of the PAHs, participating in the structure of the dioxygenases enzymes. Some authors have evaluated the structure of and the cleavage of the aromatic ring by intradiol enzymes such as $\mathrm{P} 3,4 \mathrm{O}$ (Bertini et al., 1995). Through these studies, it was possible to observe that the presence of the $\mathrm{Fe}^{3+}$ increased the activity of these enzymes for degradation by the cleavage orientation in the aromatic ring and because this trace element is part of the molecular structure of these enzymes as well as cofactor in the prosthetic group (Harayama et al., 1992). This could help explain the effect of iron in increasing $\mathrm{P} 3,4 \mathrm{O}$ enzyme activity.

The strong inhibition caused by ammonium sulfate, even with the immobilized extract, is related to the fact that ammonium sulfate can destructure the conformation of the alginate due the presence of dissolved ions (Ishibashi et al., 1990). Other negative effect of the ammonium sulfate on cell-free extract can be promoted by the denaturation of the proteins breaking the hydrogen bonds and disulfide. This inhibitory effect was illustrated with Pseudomonas putida by Ishibashi et al. (1990).

Protocatechol 3,4-dioxygenase activity was high at $\mathrm{pH} 7.0$ in the phosphate buffer, and at $\mathrm{pH} 8.0$ in the Tris-HCl buffer. Maximum activity was thus influenced both by variation in $\mathrm{pH}$ and by the change of buffer. Bull and Ballou (1981) and Buchan et al. (2000) reported the greatest activity for this enzyme at $\mathrm{pH} 8.0$ in phosphate buffer, and in the $\mathrm{pH}$ range between 8.0 and 9.0 in the Tris- $\mathrm{HCl}$ buffer. For this enzyme it is thus impossible to determine the optimum $\mathrm{pH}$ without looking at the buffer, since the buffer promotes activity, probably through the type and quantity of dissolved ions in the solution. However, the phosphate buffer promoted high activity across a wide $\mathrm{pH}$ range, and is thus more useful for bioremediation.

The cell-free extract of the $\mathrm{P} 3,4 \mathrm{O}$ enzyme showed a high relative activity, close to $80 \%$, at $15^{\circ} \mathrm{C}$, and activity continued to increase up to $35{ }^{\circ} \mathrm{C}$. This shows that this enzyme has a high biotechnological potential for use in the treatment of effluents contaminated with PAHs, due to the high activity in the temperature range between 15 and $40{ }^{\circ} \mathrm{C}$ for the cell-free extract. High tem- 
peratures, up to $35^{\circ} \mathrm{C}$, decreased the cell-free extract enzyme activity. Optimum temperatures for dioxygenase enzyme activity can vary. This variation is due to the isolate that produces the enzyme for biodegradation, and the optimum temperature range has been reported to range between 25 and $85{ }^{\circ} \mathrm{C}$, depending on the isolate species (Yang et al., 2008).

The use of enzymes is promising. Some practical problems remain with regard to the free forms, including the instability of the structure when it is removed from its natural environment and processed in nonoptimum conditions, which promotes low stability and short enzyme activity times. With enzyme immobilization, the system stabilizes the enzyme structure, making it more resistant to environmental conditions. Immobilized enzymes are easily recovered and can be reused in enzymatic processes of continuous operation for a large variety of uses in different models of bioreactors (Krajewska, 2004). Immobilized enzymes can also be used in a wider range of environmental conditions than cellfree extracts, and thus appear to be the best choice for biodegradation under a variety of environmental conditions.

\section{Conclusions}

$\mathrm{Fe}, \mathrm{Mn}$, and $\mathrm{Cu}$ can improve $\mathrm{P} 3,4 \mathrm{O}$ enzyme activity, and are important amendments for biodegradation. The immobilization of the crude extract can help protect the $\mathrm{P} 3,4 \mathrm{O}$ enzyme and increase enzyme activity with cations $\left(\mathrm{K}^{+}\right)$, trace elements $\left(\mathrm{Hg}^{+2}\right)$, and environmental conditions such as $\mathrm{pH}$, temperature, and time. The use of phosphate buffer promoted high enzyme activity for the $\mathrm{P} 3,4 \mathrm{O}$ across a wide $\mathrm{pH}$ range. The isolate Leifsonia sp. showed important characteristics for biodegrading phenanthrene, producing high quantities of the $\mathrm{P} 3,4 \mathrm{O}$ enzyme that forms part of the most important pathway for PAH biodegradation and which can be used in bioreactors for bioremediation.

\section{Acknowledgements}

This project was supported by CAPES (Coordenação de Aperfeiçoamento de Pessoal de Nivel Superior) and $\mathrm{CNPq}$ (Conselho Nacional de Desenvolvimento Científico e Tecnológico), Brazil.

\section{References}

Bertini, I.; Briganti, F.; Mangani, S.; Nolting, H.F.; Scozzafava, A. 1995. Biophysical investigation of bacterial aromatic extradiol dioxygenases involved in biodegradation processes. Coordination Chemistry Reviews 144: 321-345.

Buchan, A.; Collier, L.S.; Neidle, E.L.; Moran, M.A. 2000. Key aromatic-ring-cleaving enzyme, protocatechuate 3,4dioxygenase, in the ecologically important marine Roseobacter lineage. Applied and Environmental Microbiology 66: 46624672 .
Bull, C.; Ballou, D.P. 1981. Purification and properties of protocatechuate 3,4 dioxygenase from Pseudomonas putida. Journal of Biological Chemistry 256: 12673-12680.

Caldwell, D.R. 2000. Microbial Physiology and Metabolism. 2ed. Star Publishing, Belmont, CA, USA.

Chang, C.H.; Lee, J.; Ko, B.G.; Kim, S.K.; Chang, J.S. 2011. Staphylococcus sp. KW-07 contains nahH gene encoding catechol 2,3-dioxygenase for phenanthrene degradation and a test in soil microcosm. International Biodeterioration and Biodegradation 65: 198-203.

Costantini, A.S.; Gorini, G.; Consonni, D.; Miligi, L.; Giovannetti, L.; Quinn, M. 2009. Exposure to benzene and risk of breast cancer among shoe factory workers in Italy Source. Tumori 95: 8-12.

Degaldillo, R.; Roduguez-Nogales, J.M. 2005. Stability and catalytic kinetics of microencapsulated $\beta$-galactosidase in liposomes prepared by the dehydration-rehydration method. Journal of Molecular Catalysis B: Enzymatic 33: $15-21$.

Durán, N.; Esposito, E. 2000. Potential applications of oxidative enzyme and phenoloxidase-like compounds in wastewater and soil treatment: a review. Applied Catalysis B: Environmental 28: 83-99.

Fernandez-Lafuente, R.; Guisan, J.M.; Ali, S.; Cowan, D. 2000. Immobilization of functionally unstable catechol 2,3dioxygenase greatly improves operational stability. Enzyme and Microbial Technology 26: 568-573.

Fujisawa, H.; Hayaishi, O. 1968. Protochatechuate 3,4Dioxygenase. Journal Biology Chemistry 243: 2673-2681.

Giedraityte, G.; Kalediene, L. 2009. Catechol 1,2-dioxygenase from $\alpha$-naphthol degrading thermophilic Geobacillus sp. strain: purification and properties. Central European Journal of Biology 4: 68-73.

Harayama, S. 1992. Functional and evolutionary relationships among diverse oxygenases. Annual Review of Microbiology 46: 565-601.

Ishibashi, Y.; Cervantes, C.; Silver, S. 1990. Chromium reduction in Pseudomonas putida. Applied Environmental Microbiology 56: 2268-2270.

Jacques, R.J.S.; Okeke, B.C.; Bento, F.M.; Peralba, M.C.R.; Camargo, F.A.O. 2007. Characterization of a polycyclic aromatic hydrocarbon-degrading microbial consortium from a petrochemical sludge landfarming. Bioremediation Journal 11: $1-11$

Jacques, R.J.; Okeke, B.C.; Bento, F.M.; Peralba, M.C.; Camargo, F.A.O, 2009. Improved enrichment and isolation of polycyclic aromatic hydrocarbons (PAH)-degrading microorganisms in soil using anthracene as a model PAH. Current Microbiology 58: 628-34.

Janbandhu, A.; Fulekar, M.H. 2011. Biodegradation of phenanthrene using adapted microbial consortium isolated from petrochemical contaminated environment. Journal of Hazardous Materials 187: 333-340.

Kahng, H.Y.; Cho, K.; Song, S.Y.; Kim, S.J.; Leem, S.H.; Kim, S.I. 2002. Enhanced detection and characterization of protocatechuate 3,4-dioxygenase in Acinetobacter lwoffii K24 by proteomics using a column separation. Biochemical and Biophysical Research Communications 295: 903-909. 
Krajewska, B. 2004. Application of chitin and chitosan based materials for enzyme immobilizations: a review. Enzyme and Microbial Technology 35: 126-139.

Mishra, V.; Rup, L.; Srinivasan, A. 2001. Enzymes and operons mediating xenobiotic degradation in bacteria. Critical Reviews in Microbiology 27: 133-166.

Ohlendorf, D.H.; Weber, P.C.; Lipscomb, J.D. 1987. Determination of the quaternary structure of protocatechuate 3,4-dioxygenase from Pseudommonas aeruginosa. Journal of Molecular Biology 195: 225-227.
Tao, X.Q.; Lu, G.N.; Dang, Z. 2007. A phenanthrene-degrading strain Sphingomonas sp. GY2B isolated from contaminated soils. Process Biochemistry 42: 401-408.

Yang, X.; Xie, F.; Zhang, G. 2008. Purification, characterization, and substrate specificity of two 2,3-dihydroxybiphenyl 1,2dioxygenase from Rhodococcus sp. R04, showing their distinct stability at various temperatures. Biochimie 90: 1530-1538.

Zaborsky, O.R.; Schwartz, R.D. 1974. The effect of imidoesters on the protocatechuate 3,4-dioxygenase activity of Acinetobacter calcoaceticus. FEBS Letters 46: 236-238. 